\title{
Anthrovision
}

Vaneasa Online Journal

Vol. 7.2 | 2019

Epistemic Disobedience

\section{Can Ethnographic Filmmaking Truly Be Shared?}

Revisiting my Filmic Collaboration with an Invisible Refugee

\section{Tami Liberman}

\section{(2) OpenEdition \\ Journals}

Electronic version

URL: http://journals.openedition.org/anthrovision/5547

DOI: $10.4000 /$ anthrovision. 5547

ISSN: 2198-6754

Publisher

VANEASA - Visual Anthropology Network of European Association of Social Anthropologists

Electronic reference

Tami Liberman, "Can Ethnographic Filmmaking Truly Be Shared?", Anthrovision [Online], Vol. 7.2 | 2019,

Online since 10 November 2020, connection on 01 February 2021. URL: http://

journals.openedition.org/anthrovision/5547 ; DOI: https://doi.org/10.4000/anthrovision.5547

This text was automatically generated on 1 February 2021.

(c) Anthrovision 


\title{
Can Ethnographic Filmmaking Truly Be Shared?
}

\author{
Revisiting my Filmic Collaboration with an Invisible Refugee
}

Tami Liberman

\section{Introduction}

\begin{abstract}
A scene in the film Napps - Memoire of an Invisible Man (2014) portrays a sunny day in lively Görlitzer Park in Berlin. I walk across the fresh grassy terrain of the western part of the park, examining from afar Africans standing beside the gravelly path in groups of 3 or 4 , who are themselves examining their surroundings as they converse. Not far from the tens of visitors sitting, talking, laughing outside the park's café, I notice a dark-skinned man in a light jacket standing alone in the shade of a tree. I approach him, smile and say that I am working on a film and looking for someone who would agree to tell me about himself. The man smiles back, but his smile is never seen in the scene, nor is he seen himself. This scene is in fact a recreation of my first real meeting with Mr. X. When this meeting actually occurred, it was still January. Mr. X was standing on the other side of the park under the branches of naked trees, covered in a heavy dark winter coat, vividly contrasting the white surface of the empty and silent snowy park. "You know, I am a journalist, and I studied photography" he said to me when I told him about the film that I wanted to make. We both smiled at the potential of a joint project. He gave me his phone number.
\end{abstract}

1 In the past decade, the interest in collaborative ethnography has been on the rise. Collaboration with members of a researched community was the center of many discussions in the 2008 American Association's annual meetings (Haley 2009: 577). Moreover, due to its ability to create a rich polyphonic ethnographic text and maintain a research ethically conscious to the subjective experience of the so-called Other, collaboration has been endorsed as a potential "twenty-first-century standard of research practice" (Fluehr-Lobban 2008: 181). Yet, the collaborative practice was examined in the field of cinema already in the 1950s, specifically in filmic experiments 
of the ethnographic filmmaker Jean Rouch (Henley 2009: 309). Films such as Moi, Un Noir and (1958), Petit à Petit (1971) display an improvisational role-play of Rouch's West African protagonists, which according to him determined the film's narrative, and thus challenge the conventional hierarchy between socio-cultural researchers and researched Others (Rouch 1978: 8). The choice to replace the researcher's control over the ethnographic text and over the knowledge that it provides about the Other with an improvised dialogue parallels in a way the ethical approach developed in the 1960s, specifically by Emmanuel Levinas. Levinas criticizes the emphasis of Western thought on knowledge, and calls to abandon ontology in favor of ethics as "first philosophy" (1979: 46-47). His view challenges the raison d'être of ethnographic knowledge, just as the use of visual media challenges conventional written ethnography. This ethical stance played a central role in the filmic experiment on which I embarked in 2014 with a West-African refugee, to whom I shall refer as Mr. X.

2 In the filmic collaboration Napps - Memoire of an Invisible Man, Mr. X performed as the main protagonist, yet could not appear on camera. Due to his political status, Mr. X was banned from working legally in Berlin. Hence, he was forced, out of cautionary measures, to conceal his identity and share the story of his exile while remaining offscreen. Instead, Mr. X, then an amateur photographer, took the role of cinematographer and thus became a collaborator in a film about his own invisibility. Through the portrayal of his forced invisibility, Mr. X embodies the experience of instability of many migrants living in nation-states in which they do not enjoy citizen rights (Beneduce 2008: 506). Furthermore, the migrants lose the possibility to publicize their story in mass media, out of the need to stay invisible. As they lose control over their own story, it remains in the hands of videographers and storytellers mostly in service of mainstream media. In my collaborative project, I aimed at both confronting and bypassing the lack of control of my protagonist and collaborator over his own story and image. In the following text I shall revisit Napps and examine the ethical and epistemological effect of Mr. X's position behind the camera through Levinas's ethical approach towards what he calls the "irreducible Other", as will be detailed further. I shall expand on the influence of this approach on critical theories in the field of documentary and ethnographic film, and apply it in the analysis of Mr. X's and my film, while exploring the following question: How can a collaboration with an African migrant in the making of a film about his/her experience in diaspora serve the purpose of constituting a new kind of subjectivity, an irreducible Otherness? Can this form of collaboration truly stand up to its ethical aspirations?

This media file cannot be displayed. Please refer to the online document http:// journals.openedition.org/anthrovision/5547

Video link: https://vimeo.com/96679622

\section{Collaboration out of Constraint}

4 My choice to make a collaborative film with a man unable to show his face was organically born out of the understanding of the representational constraint he faced. When I first met Mr. X in the park in Berlin, I knew nothing about his legal status in Germany, and so never thought to suggest that he join me behind the camera. In our 
first scheduled meeting, my initial questions to him were general and vague. I was interested in various themes for my film, none of which referred to the experience of "illegality". Over a cup of cappuccino, Mr. X, began sharing his story: after escaping from West Africa (for reasons that cannot be revealed), he sought asylum in Italy. Following a 6-month wait in a refugee camp in Foggia, he was granted his residence permit as a refugee. He learned Italian in 6 months, studied photography and worked on a project with an online newspaper. Having completed the project, Mr. X was faced with financial duress directly triggered by the economic crisis, which led to difficulty in absorbing refugees and foreign job seekers. ${ }^{1}$ Finding it practically impossible to reach financial independence and being forced to join the black labour market where he competed for jobs against large crowds of undocumented migrants, Mr. X decided to move to Berlin using the travel documents he received from the Italian authorities. Though excited to move "because it was an adventure" as he said, Mr. X knew he would have to reside in Berlin without work permit due to the Dublin I and II regulations. ${ }^{2}$ Upon hearing about his legal status, I asked Mr. X: "Can you in fact appear in front of the camera?" "No," he said shyly. I pondered for a moment. "So, what if instead, you shoot the film?" Mr. X said he was interested.

5 This idea to place Mr. $\mathrm{X}$ behind the camera rather than in front of it led to the forming of a kind of representation of "illegality" in which Mr. X's face remains invisible while his audible narration expresses his subjective voice. Before I move on to contextualizing this choice politically and epistemologically, I should mention that this choice emerged much more from the dynamic and the chemistry with Mr. X than from rational thought or critical aspiration. While telling me his story, Mr. X's warm voice resonated with what felt like the weight of a whole personal history. Yet at the same time, there was something light, humorous and poignant about his delivery. It implied that his speech, words, tone, could construct a strong cinematic presence without having to rely on visual representation; that, despite his absent figure, his voice could embody his subjective Self. As David MacDougall says, "voices are more completely embodied in a film than faces, for the voice belongs to the body. Visual images of people, by contrast, result only from a reflection of light from their bodies... whereas a voice emanates actively from within the body itself: it is a product of the body" (1998: 263). This ability to portray the body is, to MacDougall, a major potential of filmmaking as an ethnographic tool. If a written text succeeds much more than film in expressing analytical generalities about unique cultural habits and patterns, then, conversely, film can depict the human body in a manner that allows the ethnographic portrait to include concrete physical, psychological, emotional attributes - elements shared by all human beings. This inclusion of human similarities that transcend cultural varieties suggests a broad perception of the field of ethnography and its anthropological purpose: ethnographic research as Karen O'Reilly argues, is capable of producing a rich account of daily lives of human subjects in a manner that respects the irreducibility of human experience and agency (2005: 3). Film, as an audio-visual representation of the body, extends this definition of an irreducible Self to include in it human qualities that are "'outside' culture" and that can be shared and empathized with through the synchrony of the filmed body with the body of the viewer-listener (MacDougall, 1998: 260).

6 At that early point in our interaction, the potential of Mr. X's voice to induce empathy within the viewer beyond cultural differences was unconsciously palpable, but along 
with it, I imagined a second potential and subversive quality that his narration might hold: creating a ghost-like presence of a person who is forced to be invisible and yet is always there, a disembodied voice that haunts the screen, and forms a reminder of a subject who is not seen, but who shall be heard.

\section{Constructing a Counter-representation}

7 The main representational choice in my ethnographic film project - to conceal the body and emphasize the voice - stands in contrast to the common portrayal of African migrants in Western mainstream media, as well as to the cultural and socio-political perception of African migration that this portrayal endorses in the public discourse. Generally speaking, such representations construct the migrants' identity as either agentless victims or as a threat of unstoppable infection through the accentuating of their bodies and the erasing of their voices (Falk 2010: 89). This common portrayal in visual media involves a construction of stereotypes using visual metaphors, such as the wide night-vision shots portraying migrants as a green faceless mass resembling toxic pollution (Cisneros 2008: 581). Another example is a display of authorities using gloves and protecting masks around migrants, which associates them with a pandemic. One can also find visual associations to Christian motifs displaying migrants as passive martyrs. These visual metaphors serve the common and at times generalizing or inaccurate press coverage, which leads to the public's perception of migrants as potential terror threat, economic concern and demographic problem (de Haas 2008: 1305). Additional inaccuracies in the portrayal of African migrants have shaped their conventional public image - as masses of uneducated African boat people driven by extreme poverty, tribal warfare and starvation, rather than people who are often from countries that have gone through economic development and are of reasonably well-off backgrounds (Flahaux and de Haas 2016: 23). ${ }^{3}$

What mainstream media coverage of the migration issue tends to omit is the nationstate's involvement in the construction of illegalization of migration (Falk 2010: 96). This construction can be traced back to the very beginning of the phenomenon of migration, along with the rise of the modern sovereign nation-state, as Hanna Arendt claims (1979). The nation-state's sovereignty, defined by "homogeneity of population and rootedness in the soil" (1979: 270), offers no solution for minorities and "stateless" people, i.e. refugees not lucky enough to have been born within the borders of a nationstate so as to enjoy basic human rights accompanying citizenship (1979: 285; 293). Along with this construction of migration, which is kept concealed from the public discourse, one might wonder whether, despite its explicit condemning, migration is not in fact discreetly tolerated and even desired in European and other countries relying on migrant labour (de Haas 2008: 1315). This discrepancy between the representation of migrants and their actual position in Western society is also noticeable when examining the spaces in which they are mostly represented. Through visual media, migrants only become visible at the borders, and thus mark the borders by their very existence. However, once they are inside Europe, thus blurring the boundaries between "outside" and "inside" the "fortress of Europe", they are often erased from the public discourse (Falk 2010: 96). ${ }^{4}$ highlighting the experience of a migrant and refugee within Europe, not at the borders, 
not just in the camps. Moreover, the methodology and aesthetic approach that I envisioned for this filmic experiment would themselves be a kind of infiltration of the fortress of Europe, not the political one necessarily but rather the fortress of mainstream media representation. I decided to meet again with $\mathrm{Mr}$. $\mathrm{X}$ and share with him my vision of this counter-representation: it would be an ethno-biography, a story of one refugee's experience within and outside the local cultural environment; it would be a work in which Mr. X could perform both as a film subject and as a partner in the screenwriting process, and recount stories of his life which we would record and then recreate or illustrate with the camera; it would be a filmmaking process in which, although directed to some extent by me, Mr. X could choose what to place in the film's frame. Thus, while having lost control over his own visual representation due to his political status, in this film he would evade the camera's gaze and obtain a gaze of his own, surveilling others instead of being himself under objectifying surveillance. I hoped that, through his control over the representation of the surrounding world, Mr. $\mathrm{X}$ would enjoy an experience of empowerment as a man who sees but cannot be seen. In addition, through his framed invisibility, the film could draw attention to the politicalcultural order of the common objectifying representation in mass media, while also reversing it. Finally, our very collaboration could challenge the conventional objectifying representation and redefine the relationship between the traditionally active image-maker and forcibly passive migrant.

\section{Ethics in Representation of Migration}

10 When I arrived at my second meeting with Mr. X, ready to share my filmic vision with him, I was also loaded with legal information, and hence full of apprehension that Mr. $\mathrm{X}$ might reject our collaboration due to its inevitable peculiar conditions. Mr. X and I sat down in the same café at Kottbusser Tor where we first met, and before we ordered I expressed my ideas about a shared project, clarified that the project would take several months, and said that unfortunately I could not grant him copyright, retribution or public recognition as my collaborator, as long as he did not obtain a work permit in Germany. Mr. X said he didn't mind the money. He wanted to work on interesting projects. Our work officially began.

11 Even with this verbal agreement, which we later sealed with a legal contract as shown in the film, no legal arrangement could cover the ethical questions that arise from a project in which I, as a director, make use of the subjective point of view of a person whose legal status differs from mine. Before I move on to discuss the ethical complexity of my experiment, I shall first analyze the ethical stance that this experiment takes with regard to the objectifying representation of African migrants in mainstream media - through the prism of Levinas's study of ethics (1979).

The common representation of African migrants in mainstream media which, as mentioned before, focuses on the migrants' presence at the borders of Western countries rather than on their life within the nation-state, nurtures the dehumanizing demarcation of African migrants as Others. Being outsiders, the migrants define the members of the nation-state as the Self situated at home or chez soi, to borrow Levinas's term (1979: 37). The sense of being at home, mentioned here in a culturalpolitical context, plays for Levinas an epistemological role. Levinas equalizes the attitude of "chez soi" to a thinker's act of self-identification that consists in defining - 
and thus possessing - "the other of the world". He refers to this attitude as "sojourning", which reduces the Other to a system of references created within the world of the Self, to categories of knowledge denying the Other's alterity. This alterity is not the formal "simple reverse of identity". Rather, it is an irreducible Other, an alterity that defies through its very being the "imperialism of the same" (1979: 36-39). Once the Other is reduced to the same, to generality, his/her individuality is diminished (1979: 44). As Levinas sees it, reduction of the Other's alterity to sameness is the basis of Western thought which places ontology as its first and foremost philosophy (1979: 43). To him ontology is a philosophy of ego, of power and injustice, as it places the freedom of exploitation over ethics (1979: 44-46).

13 According to Donald Martin Carter's research about the African diaspora in Europe (2010), the otherness of these "other cultures" of the migrants, which differentiates them from the local Western culture, has a grave effect on the decision to exclude them from society. The consequential state of "invisibility" of the migrant, as termed by Carter, devalues their subjectivity and leaves their presence unacknowledged (2010: loc 175). Furthermore, Carter notes the complex relations between the migrants' invisibility and their "hypervisibility", which, as noted earlier, is also expressed by the excessive reportage of their presence at the borders of the nation-states they wish to enter: the invisible marks the outline of the visible, which could not delineate itself without the invisible bordering it (Carter 2010: loc 171).

This political and cultural manifestation of the forceful possessing of an irreducible Other acts as a form of oppression. If we consider that cultural identity is not a fixed entity untouched by history and social change but rather a positioning, the possession and appropriation of the irreducible Other can shape the Other's identity accordingly (Hall 1990: 226; 236). In the case of the African diaspora, says Carter, their experience of invisibility as a cultural identity, conceived through man-made construction of a specific political system, can be gradually woven into cultural traditions and become a taken-for-granted and conventional perception of reality (2010: loc 455).

Going back to the subject of visual representation, photographic depictions are said to have the ability to perform two parallel processes associated with the social construction of identity: the construction of reality through the visual representation and the naturalization of this construction to the point where it seems part of the reality constructed by it (Carter 2010: loc 1529). Thus, images play a crucial role in implanting stereotypes into a culture. However, the visual discourse has the power not only to depict people in a stereotypical, demeaning manner, but also to offer a different, subjective portrayal - as agents. Stuart Hall calls for cinematic representation of migrants, noting its importance "not as a second-order mirror held up to reflect what already exists, but as that form of representation which is able to constitute us as new kinds of subjects" (1990: 236-237). However, the illegalization of many migrants prevents them from realizing Hall's vision, as it denies them the right to appear before camera, raise funds for films or distribute them (Grassilli 2008: 1245).

A collaboration in which the legal status of a citizen-filmmaker is used to help share the story and point of view of a non-citizen is a potential solution to the lack of direct access of illegalized migrants to media channels, and to the consequential effacement of their subjective experiences from Western public discourse. Of course, from a purist point of view this is not a flawless solution, as the authority is never solely at the hands of the non-citizen. At best it is shared, and most likely it remains at the hands of the 
citizen-filmmaker. When we embarked on the project, I naively disregarded the complexity of this matter of authority that the project raised, and with which I was confronted later on. At this point, what I mostly sensed was the potential of the indepth dialogue between Mr. X and me that the collaborative ethnographic approach opened up.

In order to construct the film's narrative, Mr. X began telling me, in a series of encounters, about his life. Our open-ended talks were set so as to allow for a flow of consciousness on the part of Mr. X, in which he would be free to draw landscapes that could exist outside of my cultural and personal frame of thought. Once in a while I used non-directive questions leading to data that could serve the film's narrative. At times we actively engaged in "brainstorming", deliberately searching for experiences suitable for cinematic scenes. A part of this dialogue was also dedicated to my telling Mr. X about myself in order for us to create a mutual sense of familiarity.

This form of dialogue, on which I shall further elaborate shortly, follows the path paved by Levinas in his critique of the centrality of ontology and its reduction of the Other to familiar categories. In order to acknowledge and accept the irreducible Otherness of the Other and replace ontology with ethics as a main philosophy, Levinas promotes the use of a face-to-face encounter, a dialogue with the Other. The proximity that the faceto-face encounter creates keeps the Self from gazing at the Other from afar, from generalizing this Other according to a set of qualities and themes, and forces the Self to notice the personal expression of the face. Levinas stresses that this conversation naturally still separates the Self from the Other and so does not eliminate the egoism inherent to this separation, but it places the right of the Other's existence over the ego (1979: 40). This form of ethical relationship relinquishes the inscription of a totalizing history which unjustly ignores the Other's Otherness, and promotes a history of dialogue between human beings, which allows an acceptance of an irreducible quality, what Levinas defines as an infinity (1979: 52). In line with Levinas's theory, once my face-to-face encounter with Mr. X was established, the irreducible quality of his complex identity seemed irrefutable. During four meetings, each lasting about two hours and consisting of a general conversation about Mr. X's life, images of Italy, West Africa and Berlin began to take shape, and with them the intricate image of a journalist, music lover, practitioner of Islam, student of photography, resident in a refugee camp, worker in an Italian farm, child in an African compound. We gradually learned to converse more clearly, getting used to each other's accents. Mr. X once told me that not one of the various languages he spoke was fluent, be it his English, Italian, Arabic or Mandinka, the language of his ancestral tribe.

These fragmentary stories, which could not be condensed into a simplified, fixed cultural identity, started materializing into scenes in my mind. I envisaged the locations in these stories being reflected through images of similar Berlin locations, which, being shot empty, would become in a way actors re-enacting ghosts, memories that can no longer be reached. Furthermore, I sensed that the linear nature of the audio-visual medium could be used to express Mr. X's complex individuality. I imagined how, in the editing stage of the film, different scenes representing different experiences from different times could be spliced together in a non-chronological order. With this fragmentary style we could bring together different cultural and social spheres that affected Mr. X throughout his life while breaking the orderly manner in 
which an identity is expected to be presented. Thus, the film structure could itself challenge the reduction of Otherness to familiar formulas.

Before our sixth meeting, I emailed Mr. X a description of the scenes I envisaged: a scene in an internet café, another in the park, yet another in the activists' refugee camp at Oranienplatz. I asked for his opinion and inquired if he could think of ideas for more scenes. He arrived at the next meeting with a suggestion for a new scene that we could shoot at Checkpoint Charlie - a tale about one of Mr. X's neighbours in Africa, who in the 1980s constructed a wall next to his compound and named it Berlin Wall. This idea eventually became the first scene we would shoot, and one of the few scenes looking back at Mr. X's life at his far-removed African home. It was also during the shooting of this scene that I first encountered the challenges of shared authority.

\section{Levinas's Other, Ethnography and Film}

When Mr. X and I met for the first shoot at Checkpoint Charlie, I gave him a few directions: "Shoot as if you're a ghost who no one can see". Entering the unfamiliar terrain of collaboration, I felt unsure how to balance the relationship with Mr. X: I suddenly feared relinquishing my control by putting this scene in Mr. X's hands; at the same time, I was afraid that I might smother his creativity. I could not decide: should I train Mr. X, who was more familiar with still photography, how to work with video? Would such training harm his spontaneity? As the scene existed solely in my head, and I failed to fully communicate it to Mr. X, he took the shots with no beginning and end point. Ironically, out of a desire not to patronize Mr. X with technical instructions, I took the camera from his hands and began taking shots just "to be on the safe side". In the editing room, my extra shots eventually proved redundant. They just were not as good as Mr. X's.

As we shot three more of our planned scenes in Berlin, the work still seemed quite rigid. Our somewhat peculiar distribution of roles was a construct still in development. The nature of our work, however, changed when we travelled, along with Mr. X's landlady, to a four-day African music festival in Würzburg in the south of Germany. Mr. $\mathrm{X}$ and I were suddenly tourists together, in a place unfamiliar to both of us. Moreover, reality forced us to improvise: on the second day of the festival, a storm flooded Southern Germany, leading to the cancellation of most of the events. None of the shots I had planned for this festival could be made. We found ourselves wandering aimlessly around town for whole days, awaiting the evening shows which still took place, but for which we did not have the rights to shoot. Out of this "togetherness" a new dynamic emerged. Mr. X started shooting scenes and capturing images on his own initiative. Having accepted the change of plan imposed on us, I found myself more at ease with the haphazard filming of scenes. A significant moment occurred when, having realized no photography was allowed of the festival's concerts, Mr. X suggested that we sneak the camera in and shoot the audience members reacting to the live music. He shared this thought with me mere seconds after the same idea came to my mind. At this moment I felt we had developed an understanding, a kind of synchrony.

At the same time, I could not ignore the fact that, as I initiated the collaboration, chose the theme and was to edit the material, Mr. X might not feel fully "at home" in my cinematic construct. But within its limitations, our role play became more and more flexible with each scene that we shot since Africa Festival. One day, back in Berlin, Mr. 
$\mathrm{X}$ called me about a big musical happening in the park, which he suggested incorporating in the film. Conversely, before shooting a scene showing African souvenirs in Mr. X's landlady's flat, Mr. X asked me to give him exact instructions how to shoot. A scene in which Mr. X interviews his landlady was initiated by me, but the questions were chosen by Mr. X. Finally, a sequence displaying Mr. X's mundane daily routine at home was shot at my request but by Mr. X alone, without my presence or my direction. This independently-shot sequence, which represents the experience of a man in limbo awaiting his full legal status, is to me a direct proof of Mr. X's creative sensibility, as well as proof of the value of relinquishing one's control.

This artistic dialogue shared by Mr. X and me during the film shoot can be seen as a continuation of our face-to-face encounter, but in a different setting, not that of verbal exchange, as playful as it may be, but rather of active creation. One might wonder why such activity belongs in ethnographic research and whether it is of any anthropological value at all, as it is not an examination of everyday habits and repeating rituals but rather a study of a unique happening, a filmic collaboration artificially constructed for the sake of my research. In answering this, Levinas's ethical approach again comes in handy, specifically in its application in documentary and ethnographic film theory. Michael Renov (2004) applies Levinas's ideas in his reflection on the ability of documentary film to produce an ethical conversation between the Self and the Other. He presents David MacDougall's criticism over the detached observational mode of filmmaking in which the filmmaker, pretending to be invisible, creates a filmic monologue presented as an objective documentation of reality, rather than acknowledging the effect of his/her presence over the Other (Renov 2004: 152).

As mentioned earlier, one of the first examples of an attempt to replace the monologue of the filmmaker with a dialogue with protagonists is Jean Rouch's method of shared anthropology ([1975] 2003: 96). With this practice, Rouch preceded the postmodern anthropological approach that emerged 20 years later as part of the so-called "crisis of representation" in human studies. Postmodern anthropology acknowledged that the researcher does not obtain knowledge necessarily superior to the common sense existing in everyday life about the cultural world he/she examines. Furthermore, the researcher cannot exist outside of his/her research field and dominate its every corner in a detached way. This understanding led to a new self-reflexive approach: "rather than engaging in futile attempts to eliminate the effects of the researcher, we should set about understanding them" (Hammersley and Atkinson 1983: 15-17).

In my collaborative project with Mr. X, I strove for self-reflexivity in more than one manner: Firstly, on a methodological level, I aimed at constructing with Mr. X what Barbara Myerhoff terms a "storytelling relationship", in which the traditionally passive informant serving the needs of the ethnographer is elevated to the position of storyteller (Kaminsky 1992: 129; 133). Myerhoff recognizes this relationship not as a pure accumulation of data untouched by the researcher's presence, but as an artificially circumstanced collusion of two specific individuals who meet to ethnographically examine one life. Such collision inevitably leads to a re-shaping of the informant's story, as this story would be different if it was told to someone else, at another time, in a different context and for a different cause. Myerhoff sees this specific dialogue between informant-storyteller and ethnographer-listener as a moment in which a third person is born. This third person, who "should not be mistaken for the spontaneous, unframed life-as-lived person who existed before the 
interview began", expresses an abstract "third voice", the voice of a new creation (Myerhoff 1992: 291-292). In the case of our work, the voice of a new creation was expressed through our joint shaping of Mr. X's story into filmic scenes and the construction of narrations and visual images that would not only represent his life story but also his self-reflexive perception of the camera. Secondly, on a representational level, I decided to appear on camera myself in many scenes in which Mr. X could not appear, and physically replace his presence in the filmic manifestation of his experiences. This way, I wished to intensify the deconstruction of the politics of representation by the positioning of the researcher, me, in front of Mr. X's camera, and self-reflexively challenge the traditional relation between the researcher and the observed subject.

By applying these self-reflexive techniques in an audio-visual ethnographic text rather than a written one, I followed the postmodern anthropological approach which contributed to the growing interest in experiential rather than analytical knowledge (MacDougall 1998: 93). This development led to the recognition of visual means - which until then were generally condemned by anthropologists for lacking intellectual substance - as "essentially no more subjective or objective than written texts" (Pink 2001: 1). This growing postmodern awareness brought the contemporary study of anthropology closer to Rouch's aim to dismantle the monopolization of observation by anthropologists, which he believed can be achieved through filmmaking (Rouch [1975] 2003: 98).

The intersection of film, anthropology and Levinas's critique of the centrality of ontology draws focus to the very physicality of the act of observation as well as its epistemological significance. The gaze enabled by the film apparatus, according to critical film theory, ${ }^{5}$ is not dissimilar to the "self-gratifying gaze of the voyeur", which the scientist enjoys while observing his/her subjects in a passive and detached way (Jenks 1995: 4). Thus, sight is the means of pleasure through control in cinema, just as it is the means for understanding the world in empirical science, which turned the visible into the most reliable component of reality (1995: 6). Yet, in neither the cinematic realm nor the scientific one can sight truly capture reality as a whole, as it always leaves out the infinite Otherness evading the gazing eye.

Christian Suhr and Rane Willerslev (2012), whose utilization of Levinas's concept of the infinite Other in the field of ethnographic film has been instrumental to my own research, examine the issue of film's illusion of a whole reality in the context of the representation of the Other. They follow Levinas's idea that in the face-to-face interaction the Other's face hides an invisible face, one that expresses an excess of Otherness (2012: 292). As they say, this plenitude of Otherness is ignored by the oftenused method of participant observation in ethnographic cinema. Although this form of observational cinema differentiates itself from the monologist observational tradition through a self-reflexive defiance of the film's objectivity, it still relies on undisturbed observation to create a sense of familiarity with the Other. Though it can be seen as an ethical endeavor, this method centralizes on the similarity between the Other and the Self, thus in fact reducing the Other to sameness (2012: 283-284). Suhr and Willerslev believe that the only way for cinema to express the invisible face of the Other is to sacrifice the observed subject by eliminating the synchronization of the camera with the observing eye. To them, the use of visual manipulations can construct different perspectives and thus express an ever-changing existence of Otherness that cannot be 
captured whole by camera (2012: 293-294). As expressed earlier, I did not shy away from creating in my film a sense of familiarity with Mr. X. Although such practice can be linked to Levinas's "imperialism of sameness", I did in fact want the viewer to identify and empathize with Mr. X through his narration. However, I hoped that through the emphasis on the absence of the film's main character from the screen - a visual manipulation that the eye cannot ignore - the viewer will not only acknowledge the cultural and political constraints Mr. $\mathrm{X}$ is facing, but also become conscious that there are elements that he/she is not privileged to see, access or control. Having the subject of the film escape his being reduced to a conventional representation of an African migrant, I hoped Mr. X's viewpoint on his surroundings combined with his subjective narration could construct an unusual cultural experience - an audio-visual manifestation of Levinas's concept of the invisible face. With this representation I intended to expose the selective nature of the visual image, and of sight and vision altogether. I wanted to challenge the viewer's gaze, having him or her acknowledge the invisible, the different, the culturally diverse which cannot become part of a false image of a whole reality.

As much as I wished for Mr. $\mathrm{X}$ to use the representational constraints imposed on him as means of resistance against the political-cultural order, our time working together showed me that this attempt did not necessarily lead to the results I expected. When I suggested taking a shot of groups of Africans standing at the side of the pathway, Mr. X expressed reluctance. He did not want to be associated with an illegal act. "But,", I said, "your name is not mentioned". "Even though" he replied, "There are many people - Germans, Arabs, Turks - that deal in the park, but when the African does it, it's the talk of town. And I cannot explain to them that, you know, I am not' part of them, nobody will believe in me". Even as an anonymous voyeur, Mr. $\mathrm{X}$ did not feel released from a surveilling gaze. This proved that the vision that ignited the project, a vision conceived within me, was in fact contested by reality. It was contested by Mr. X's sincere emotions. And yet his emotions are now depicted in one of the scenes of a film created according to this contradictory vision. Does this mean that I managed to merge my voice and Mr. X's together into what can be perceived as the Myerhoff's "third voice"? Or was I plainly using my authority to appropriate Mr. X's story and shape it to fit my needs? This question followed me into the editing room where I mostly worked alone. Although my editing choices were examined, approved and at times suggested by Mr. X, the subjective flow of ideas and stories that the editing expressed was still created by me, and yet the point of view that the images reflect suggests that it is the subjective flow of ideas of Mr. X. While editing I wondered: Could taking control over the representation of Mr. X's identity be avoided, or should it be accepted? If any ethnographic text is, to a certain extent, a researcher's manipulation of "reality", does the film's fragmentary structure at least manage to expose the manipulation?

\section{Collaborative Film - A True Encounter?}

June 2014. Daytime at Görlitzer Park. Mr. X and I arrive together and start walking through the park. I tell him we need to get a shot of the Africans standing around for our scene featuring the music festival. Mr. X asks me: "Why are we shooting only Africans? Why is it important for the film?" I ask what he means. He replies: "I see myself as one guy in the middle of millions. There are a lot of Whites that are here you could be choosing before me. So it's my doubt, I 
wanted to ask". I explain that originally my interest was not in "capturing the Africans", but in finding someone who, like me, was not German and would speak to me in English, a language that would be a meeting point for both of us. "Why do you ask?" I ask him. "Because I have a skeptic mind" he says, "I don't even trust myself. I always say 'yes' to things and only later analyze it, and it never comes to my favour". We go back to work and I ask him again to shoot the Africans. "Maybe you go, and I stay here". I ask him if that's what he prefers to do. "I just don't want to embarrass my fellow-Africans. I don't want somebody is telling me a foul word[...] like, you know, you are a shit guy, you let the white girl use you to take our picture and then show it to the people".

Though it is hard to deny the ethical potential of the idea of shared anthropology and shared filmmaking, the question that reverberates throughout this text is whether it is possible to truly maintain such a democratic practice. Going back to the father of this method, Jean Rouch, it should be mentioned that not all of his experiments with collaboration met with the participants' full approval. An example is Oumarou Ganda's expressed resentment toward Rouch for falsifying his life story in the collaborative ethno-fiction film Moi, un Noir, and for excluding him from the editing process (Henley 2009: 331). Furthermore, this film is unquestionably known as a Jean Rouch film. He is the one credited and renowned for this inventive work, not his protagonists. These issues raise the question whether "shared authorship" can really be applied and whether the mechanism of film production allows for a true collaboration, a genuine escape from "the moral burden of authorship" (Ruby 1995: 80).

In his Levinasian examination of ethnographic and documentary film, Renov (2004) claims that even in reflexive and interactive documentary films, in which the filmmaker's presence and its ideological effect are acknowledged, the film remains a "conceptualization of the maker". Thus the film acts as a means of persuasion, of sharing a message that the filmmaker wishes to convey through the interaction with the Other, rather than an expression of dialogue (Renov 2004: 152). Hal Foster terms this tailoring of the Other as an embodiment of the artist's viewpoint an "ethnographic self-fashioning" (1996: 306). Renov wonders whether film - or ethnography - has the ability to avoid possessing the Other and exploiting reality: "[...] are these not the ethical limits within which all ethnographic practice must reside? [...] Can any documentary act hope to escape unscathed?" (2004: 152-153).

With this inquiry in mind, Renov turns to Martin Buber's definition of the "encounter" that emphasizes the importance of spontaneity in conversation between the Self and the Other. According to Buber, the sphere in which the two meet should not compel their individuality nor their existence as a collective, but must exist in between the familiar sphere of each. In this sphere, which the two share and yet neither of them exclusively owns, a real conversation emerges. It is a dimension which only the two of them access. Renov wonders whether the technology of film or video - which reproduces and commodifies the audio-visual representation of reality - could in fact perpetuate the spontaneity of Buber's real conversation which can only happen in "real time". Furthermore, if the sphere shared by the two interacting people must only be accessed by the two of them, one wonders how it could exist on film, which is meant to be shared with an audience (Renov 2004: 153).

In the case of Napps, there were definitely elements in the dialogue between Mr. X and me that I would define as "spontaneous", especially at the previously mentioned flooded African music festival in Würzburg. In line with Buber's idea of a sphere in- 
between the familiar spheres of the Self and the Other, Mr. X and I found ourselves in a geographically unfamiliar sphere where we began improvising scenes and recording spontaneous conversations. The spontaneous nature of our interaction, which continued later during shooting days in Berlin, led to a change in the course of the film which I could not have predicted. Such is the moment incorporated in the film, when Mr. X wonders about my decision to make a film with him: "Why would you not find a person who have a legal right to work with you?" Having placed Mr. X behind the camera in order to contest the law denying his ability to represent his story, I was surprised by his feelings that the law in Germany, determining his illegality, should be respected. In this manner, Mr. X questioned de facto the agenda behind the film's most basic feature - its reliance on a collaboration with a man of illegal status.

This clash of world views, brought together in one film, was a result, I believe, of the spontaneity and openness of our interaction, enabled by the familiarity that our collaboration generated. However, this spontaneous conversation was actually recreated for the film. Although the original dialogue that Mr. X and I shared is identical to its re-enactment which appears in the film, the fact that it was only recorded with a microphone led me to suggest to Mr. $\mathrm{X}$ to re-enact my side of the dialogue in front of the camera. This form of re-enactment, when concealed, would of course be ethically questionable, to say the least. However, the film reflexively admits to its own falsification in its beginning: in a scene portraying the moment I approach Mr. $\mathrm{X}$ for the first time and suggest we make a film together, he is already holding a camera and filming me, which naturally could not occur in real life. Through this artifice I wished to remind the viewers that generally speaking any documentary or ethnographic film is, to an extent, a directed, modified and manipulated version of reality, whether it is acted or not. Nevertheless, the re-enactment brings us back to Renov's statement that film is not spontaneous and cannot, therefore, convey the ethics of Buber's encounter.

My motive for the abovementioned re-enactment of the scene brings up the second reason for Renov's questioning the film as an encounter: its being shared with an audience. Had I not wished to incorporate our dialogue in the film and share it with viewers, I would not have re-enacted it. Thus, my wish to transmit a filmic experience to the viewers affected this scene as well as other ones. In order to tackle this tension between the intimate dialogue and the need to publicize it, I turn again to Levinas (2011). Challenging his own idea of the ethical one-on-one relationship with the Other, Levinas reminds us that these intimate and ethical relationships would unavoidably take place within a greater social and political system. He stresses the importance of systems of justice and law that depend on the ethics of face-to-face encounters at the same time as they contradict the intimacy of these encounters. In this context, Levinas defines the concept of "the third party", which represents another Other, a third who through his/her presence puts a limit to the responsibility of the Self towards the Other in their face-to-face encounter and raises the issue of public responsibilities. The relationship with the Other which, as we have seen, exists beyond categorization or thematization, when faced with the presence of the third party, is also faced with the need to be brought into consciousness, to be thematized. This third party, which represents all the Others of the world, is in need of such things as comparison and thematization, of an order through visibility of faces (2011: 157-158). Levinas calls this a work of justice (2011: 159). This work of justice can be interpreted as the evolving of the ethics of face-to-face encounters into public laws, into the order of a society. Levinas 
settles the tension between the one-on-one relationship and the universal thematization by stressing that this system of justice - the law, the state and its institutions - is not an elimination of the relationship between the Self and the Other. Rather, the one-on-one relationship with the Other gives meaning to the relationship with all the other Others. Thus, the system of justice depends on the proximity between the Self and the Other (2011: 159).

Can collaborative film settle the tension between the intimate relationship with the Other and presence of the third party - in this case, the potential viewers of the film? Can it balance the intimate and the public? Finally, can it overcome what seem to be unavoidable flaws in its claimed democracy? With these inquiries in mind, I now wish to return to a scene in the film in which the desire to find the balance between Mr. X's and my one-on-one relationship and its publicizing led, when screened, to unexpected responses from the audience. The scene I refer to is our dialogue in the park, in which Mr. X protests at my proposal to display the African people working as weed dealers and contextualizes the dealers' need to work for their survival in a trade that was neither their first choice nor their original livelihood. In order to express his fear of the danger of film, which can be misinterpreted by the viewers and affect the perception of African migrants, Mr. X presents me with a question already mentioned earlier, a question which in reality he asked twice: "Why you are only interested in shooting Africans that hang around here? Why is that, is that important to the film?" In the original shoot I answered both questions immediately, explaining my reasons for this scene as well as for the whole film. Once I was done I told him: "I hope my answer was sincere, and good.". "Anyway you can always edit it as you want", he said with a smile. Ironically, I did indeed cut my answer out of the film. The reason was my wish to allow the viewer to experience the world of the film without my authoritative analysis which was expressed in my answers. Furthermore, in my "thematization" of my encounter with Mr. X, I preferred to focus on Mr. X's voice, to give space to his worldview rather than mine. Interestingly enough, in several screenings of the film, viewers criticized my lack of answer to Mr. X's question which, as they said, created an inequality in the dialogue between us, as I only draw information from him but never supply him with any in return. Thus, my wish to avoid an on-screen "self-fashioning" of Mr. X through my reply led to the creation of a self-fashioned dialogue: $\mathrm{I}$, as the creator of the film, the one who initiated the project, used my authority to change the representation of our encounter as I pleased, even if I believed it was in the benefit of Mr. X's story. Also, ironically, it was the audience itself that noted the artificial quality of our dialogue, which I only changed for the sake of the audience's experience. In real life it was in fact more spontaneous and incidentally more balanced. One could say that in my attempt to intertwine my responsibility towards $\mathrm{Mr}$. $\mathrm{X}$ and my wish to bring our dialogue into consciousness, I stumbled on both accounts.

To conclude, the analysis of my collaboration with Mr. X supports Renov's claim that the need to bring to consciousness, present and thematize a recorded encounter with the Other might sacrifice the spontaneity of the encounter and consequently some of its ethical value. However, perhaps the balance of the intimate and the public does still exist in my film thanks to the interest of Mr. X himself in publicizing his story. Our relationship was never based on a "pure" discreet dialogue which later became tainted by its exposure to outside viewers, but on dialogue based on a shared desire to collaborate in film. Thus, this encounter was always meant for publication through visual media. This is exemplified by Mr. X's choice to incorporate the shot of the 
Africans in the park in the film despite his fear of potential misrepresentation. Having reflected on this issue for a while during the editing process, Mr. $\mathrm{X}$ finally decided that externalizing the story of people forced to work as weed dealers to a "third party" - the viewer - had significance, as long as it was accompanied by his contextualizing voice. In fact, Mr. X's belief in the significance of visual representation and preservation is voiced within the film itself, when he elaborates on his interest in photography:

It keeps me reminding the things that have passed. At times I used to ask my mom about her father, I got curiosity, whether he's a tall man, whether he's a short man, or fat, or slim-body man. Immediately when I saw the picture of him, I recognized. Yeah, it teaches you history. About the faces of the people. About how some people look like.

the ethical importance of distributing the film and sharing it with the third party. It is a necessary thematization, which sacrifices the intimacy with the irreducible Other for the sake of justice, to use Levinas's term. Nevertheless, I hope that the choice to accompany this specific recording of Mr. X with a black screen, turning the darkened frame into a metaphor of Mr. X's invisibility while allowing it to be filled with his soft voice, manages to transmit some of the intimacy of my one-on-one encounter with Mr. X.

Naturally, even if such intimacy does reach the viewers through the aforementioned scene, it will not eliminate the imperfections of collaborative ethnographic film. Its claimed ethical superiority will quite inevitably and justly continue to be questioned and challenged. However, even as a flawed form, the collaborative method enables an interaction between Others, a humanist dialogue necessary in a world in which the displacement and movement of populations from one country to another seems to be ever-growing. Furthermore, in political spheres in which groups of people are denied the opportunity to portray themselves in media, collaborative film can construct a representation that counters the common visual rhetoric offered by mainstream media, and that pushes forward a narrative that would otherwise be effaced from the pages of history. All the same, its imperfect nature also becomes an important reminder that collaborative film is no substitute to a visual representation made freely and independently by those whose legal status renders them invisible.

\section{Afterword}

In 2018, Mr. X was granted a 2-year work visa in Berlin, which since then has been renewed. As a result, he agreed to have his identity revealed as part of our film. His name, occupation in Berlin and region of origin in Africa are now shared at the end of the last scene: Muhammed Lamin Jadama, translator and cultural educator, originally from the Senegambia region. Accompanying this information is a photograph which shows his face. 


\section{BIBLIOGRAPHY}

\section{Books and articles}

Arendt, Hannah. 1979 [1951]. The Origins of Totalitarianism. New York: Harcourt Brace and Company.

Beneduce, Roberto. 2008. Undocumented Bodies, Burned Identities: Refugees, Sans Papier, Harraga - When Things Fall Apart. Social Science Information 47(4): 505-527.

Berry, Mike, Inaki Garcia-Blanko and Kerry Moore. 2015. Press Coverage of the Refugee and Migrant Crisis in the EU: A Content Analysis of Five European Countries, Report prepared for the United Nations High Commission for Refugees. http://www.unhcr.org/56bb369c9.pdf (accessed 26 October 2017).

Baudry, Jean-Louis. 1974-1975. Ideological Effects of the Basic Cinematographic Apparatus Film Quarterly 28(2): 39-47. DOI: 10.2307/1211632

Carter, Donald Martin. 2010. Navigating the African Diaspora: The Anthropology of Invisibility, Minneapolis: University of Minnesota Press. Kindle Edition.

Cisneros, J. David. 2008. Contaminated Communities: The Metaphor of "Immigrant as Pollutant" in Media Representations of Immigration. Rhetoric \& Public Affairs 11(4): 569-601.

de Haas, Hein. 2008. The Myth of Invasion: the inconvenient realities of African migration to Europe. Third World Quarterly 29(7): 1305-1322.

Falk, Francesca. 2010. Invasion, Infection, Invisibility: An Iconology of Illegalized Immigration. Images of Illegalized Immigration: Towards a Critical Iconology of Politics. Christine Bischoff, Francesca Falk and Sylvia Kafehsy, eds. Pp. 83-99. New Brunswick and London: Transaction Publishers.

Flahaux, Marie-Laurence and Hein de Haas. 2016. African Migration: Trends, Patterns, Drivers. Comparative Migration Studies 4(1): 1-25. DOI: 10.1186/s40878-015-0015-6.

Fluehr-Lobban, Carolyn. 2008. Collaborative Anthropology as Twenty-First-Century Ethical Anthropology. Collaborative Anthropologies 1: 175-182. DOI: 10.1353/cla.0.0000

Foster, Hal. 1996. Artist as Ethnographer. The Return of the Real. Cambridge: MIT Press. Grassilli, Mariagiulia. 2008. Migrant Cinema: Transnational and Guerrilla Practices of Film Production and Representation. Journal of Ethnic and Migration Studies 34(8): 1237-1255.

Haley, Brian D. 2009. Is Collaborative Anthropology Better? Current Anthropology 50(4): 577-579.

Hall, Stuart. 1990. Cultural Identity and Diaspora. Identity, Community, Culture, Difference. Jonathan Rutherford, ed. Pp. 222-237. London: Lawrence and Wishart.

Hammersley, Martyn and Atkinson Paul. 1983. Ethnography: Principles in Practice. London: Routledge.

Henley, Paul. 2009. The Adventure of the Real: Jean Rouch and the Craft of Ethnographic Cinema. Chicago and London: University of Chicago Press.

Jenks, Chris, ed. 1995. Visual Culture. London and New-York: Routledge.

Kaminsky, Marc. 1992. Myerhoff's "Third Voice": Ideology and Genre in Ethnographic Narrative Social Text 33: 124-144.

Levinas, Emmanuel. 1979[1969]. Totality and Infinity. The Hague: Martinus Nijhoff bv. 
Levinas, Emmanuel. 2011 [1981]. Otherwise than Being or Beyond Essence. Pittsburgh: Duquesne University Press.

MacDougall, David. 1998. Transcultural Cinema. Lucien Taylor ed. Princeton: Princeton University Press.

Mulvey, Laura. 1975. Visual Pleasure and Narrative Cinema. Screen 16(3): 6-18. DOI: https:// doi.org/10.1093/screen/16.3.6

Myerhoff, Barbara. 1992. Remembered Lives: The Work of Ritual, Storytelling, and Growing Older. Marc Kaminsky, ed. Ann Arbor: University of Michigan Press.

NOAS - The Norwegian Organization for Asylum Seekers. 2011. The Italian Approach to Asylum: System and Core Problems The Norwegian Organization for Asylum Seekers Internet website. http:// www.noas.no/wp-content/uploads/2013/08/Italia-rapport.pdf (accessed 13 September 2020).

O'Reilly, Karen. 2005. Ethnographic Methods. London: Routledge.

Pink, Sarah. 2001. Doing Visual Ethnography: Images, Media and Representation in Research. London: Sage Publications.

Renov, Michael. 2004. The Subject of Documentary. London and Minneapolis: University of Minnesota Press.

Rouch, Jean. 1978. On the Vicissitudes of the Self: The Possessed Dancer, the Magician, the Sorcerer, the Filmmaker, and the Ethnographer. Studies in the Anthropology of Visual Communications 5(1): 2-8.

Rouch, Jean. 2003 [1975]. The Camera and Man. Principles of Visual Anthropology. Paul Hockings ed. Pp.79-98. Berlin and New York: Mouton de Gruyter.

Ruby, Jay. 1995. The Moral Burden of Authorship In Ethnographic Film. Visual Anthropology Review 11(2): 77-82.

Russell, Catherine. 1999. Experimental Ethnography: The Work of Film in the Edge of Video. Durham and London: Duke University Press.

Suhr, Christian and Rane Willerslev. 2012. Can Film Show the Invisible? The Work of Montage in Ethnographic Filmmaking. Current Anthropology 53(3): 282-301.

Films

Liberman, Tami and Mr. X. 2014. Napps - Memoire of an Invisible Man. Markus Kaatsch, Germany (production). $31 \mathrm{~min}$.

Rouch, Jean. 1958. Moi, Un Noir. Pierre Braunberger and Roger Felytoux, Les Films de la Pléiade, France (production). $73 \mathrm{~min}$.

Rouch, Jean. 1971. Petit à petit. Les Films de la Pléiade, France (production). 96 min.

\section{NOTES}

1. For more information about the struggle for survival of many refugees in Italy, leading them at times to engage in criminal activities and prostitution and living on the street see http:// www.noas.no/wp-content/uploads/2013/08/Italia-rapport.pdf (accessed 13 September, 2020).

2. According to the Dublin I and II regulations adopted by all EU member states and other European states, asylum application cannot be submitted twice (NOAS 2011: 5; 10; 35). 
3. Germany, where Mr. X resides, has been one of the more welcoming countries to refugees in the EU and proves to produce rather empathetic press coverage of migration as compared to other European states. However, portrayals of refugees as a security threat have been displayed in newspapers representing both sides of the political map in Germany, and the portrayal of migrants and refugees as financial burden has been on the rise in right-wing oriented papers (Berry, Garcia-Blanko and Moore 2015: 259-261).

4. In the German press, there is some reporting of positive integration of refugees (for example, in the rather leftist Süddeutsche Zeitung). However, right-wing oriented papers such as Die Welt or Bild tend to report such stories briefly and without sufficient context (Berry, Garcia-Blanko and Moore 2015: 259).

5. See for example Laura Mulvey's feminist film theory (1975), Jean-Louis Baudry's cinematographic apparatus theory (1974-1975) and Catherine Russell's writing on the subject (1999: 121).

\section{ABSTRACTS}

Collaborative ethnographic filmmaking has been celebrated as a practice that ethically challenges the traditional relationship between the observing researcher and the observed Other. At the same time, the collaborative mode raises the question whether it can truly dismantle the researcher's authority as it claims. This article addresses these issues by examining the writer's collaborative film Napps - Memoire of an Invisible Man, in which the main protagonist a West African refugee living in Berlin without a work permit - stands behind the camera as cinematographer and storyteller while keeping his identity and face concealed.

The article addresses Emmanuel Levinas's critique of Western thought's emphasis on accumulation of knowledge, and his call to replace the epistemological appropriation of the Other with an ethical one-on-one dialogue. Contextualizing the migrant's political and cultural invisibility, the article parallels the Western mindset with common objectifying visual representation of African migrants in mainstream media which denies the migrants' individuality. The article references Levinas's influence on approaches to ethnographic film in order to examine collaborative filmmaking's ability to offer a more ethical representation of African migrants. It reflects on Napps's collaborative nature and its purpose to reverse the cinematic/ethnographic gaze and both bypass and confront the migrant's forced invisibility, and the underlying political, cultural and epistemological order. Finally, the article critically questions the film's ability to follow the demands of the ethical dialogue between the Self and the Other according to Levinas and Martin Buber.

La réalisation collaborative de films ethnographiques a été célébrée comme une pratique qui remet en question, d'un point de vue éthique, la relation traditionnelle entre le chercheur observateur et l'Autre observé. En même temps, le mode collaboratif soulève la question de savoir s'il peut réellement démanteler l'autorité du chercheur comme il le prétend. Cet article aborde ces questions en examinant le film collaboratif de l'auteur, Napps - Mémoire d'un homme invisible, dans lequel le principal protagoniste - un réfugié ouest-africain vivant à Berlin sans permis de travail - se tient derrière la caméra en tant que cinéaste et conteur tout en gardant son identité et son visage cachés. 
L'article traite de la critique d'Emmanuel Levinas sur l'accent mis par la pensée occidentale sur l'accumulation des connaissances, et de son appel à remplacer l'appropriation épistémologique de l'Autre par un dialogue éthique en tête-à-tête. Contextualisant l'invisibilité politique et culturelle du migrant, l'article met en parallèle la mentalité occidentale avec la représentation visuelle objectivante courante des migrants africains dans les médias grand public, qui nie l'individualité des migrants. L'article fait référence à l'influence de Levinas sur les approches du film ethnographique afin d'examiner la capacité du cinéma collaboratif à offrir une représentation plus éthique des migrants africains. Il réfléchit à la nature collaborative de Napps et à son objectif de renverser le regard cinématographique/ethnographique et de contourner et confronter à la fois l'invisibilité forcée du migrant et l'ordre politique, culturel et épistémologique sous-jacent. Enfin, l'article remet en question de manière critique la capacité du film à suivre les exigences du dialogue éthique entre le Soi et l'Autre selon Levinas et Martin Buber.

El cine etnográfico colaborativo ha sido elogiado como una práctica que, desde el punto de vista ético, desafía la relación tradicional entre el investigador observador y el Otro observado. Al mismo tiempo, el modo colaborativo plantea la cuestión de si realmente es capaz de desmantelar la autoridad del investigador, tal como plantea. Este artículo aborda estos problemas examinando la película colaborativa del autor, titulada Napps - Memoire of an Invisible Man, en la que el protagonista principal, un refugiado de África Occidental que vive en Berlín sin permiso de trabajo, está detrás de la cámara como director de fotografía y narrador mientras mantiene su identidad y cara oculta.

\section{INDEX}

Mots-clés: migration subsaharienne, statut de réfugiés, invisibilité, médias, anthropologie visuelle, anthropologie partagée, film collaboratif, éthique, Levinas

Palabras claves: $\mathrm{El}$ artículo aborda la crítica de Emmanuel Levinas al énfasis del pensamiento occidental en la acumulación de conocimiento, y su llamado a reemplazar la apropiación epistemológica del Otro por un diálogo ético de igual a igual. Contextualizando la invisibilidad política y cultural del migrante, el artículo compara la mentalidad occidental con la común representación visual objetivante de los migrantes africanos en los principales medios de comunicación, en que se les niega la individualidad. El artículo hace referencia a la influencia de Levinas en los enfoques del cine etnográfico con el fin de examinar la capacidad del cine colaborativo para ofrecer una representación más ética de los migrantes african, evitando y confrontando así la invisibilidad forzada del migrante así como el orden político, cultural y epistemológico subyacente. Finalmente, el artículo cuestiona críticamente la capacidad del cine para respetar las exigencias del diálogo ético entre el Yo y el Otro según Levinas y Martin Buber. Keywords: Sub-Saharan migration, refugee status, invisibility, media, visual anthropology, shared anthropology, collaborative film, ethics, Levinas

\section{AUTHOR}

\section{TAMI LIBERMAN}

Freie Universität Berlin

Tami Liberman is an ethnographic film scholar and video editor currently completing her PhD at the Department of Sociology and Anthropology at Tel Aviv University. She earned her BFA in Film magna cum laude from Tel Aviv University and her MA in Visual Anthropology from Freie 
Universität Berlin. Her research film Napps - Memoire of an Invisible Man won several awards and was screened in academic conferences and film festivals worldwide including Festival dei Popoli. Tami edited the $19^{\text {th }}$ issue of the Israeli magazine Takriv dedicated to the analysis and discussion of documentary film. She teaches courses in ethnographic filmmaking, ethnographic film history and film editing at Tel Aviv University, Freie Universität Berlin, Kibbutzim College and College of Management Rishon Lezion.

tami.liberman@gmail.com 